Orijinal araştırma (Original article)

\title{
Electrical Penetration Graph monitored feeding behavior of cowpea aphid, Aphis craccivora Koch. (Hemiptera:Aphididae), on faba bean, Vicia faba L. (Fabaceae), cultivars
}

\author{
Börülce yaprakbiti, Aphis craccivora Koch. (Hemiptera: Aphididae)'nin EPG yöntemi ile \\ farklı bakla çeşitleri üzerindeki beslenme davranışının belirlenmesi
}

\author{
Alan SOFFAN $^{1^{*}} \quad$ Abdulrahman Saad ALDAWOOD $^{1}$
}

Summary

Feeding behavior of cowpea aphid, Aphis craccivora Koch. (Hemiptera: Aphididae), was evaluated on five faba bean, Vicia faba L. (Fabaceae), cultivars, including the resistant cultivar Gazira2, by using the Electrical Penetration Graph (EPG) technique. Experiments were conducted on whole plants (WP) and detached leaves (DL). Fifteen parameters of EPG recording were selected for statistical analysis. Two-way factorial ANOVA showed that the EPG parameter values in WP and DL were significantly different, while the cultivars difference occurred mostly in the WP tissue, as indicated through one-way ANOVA Kruskal-Wallis analysis. Cowpea aphid feeding behavior on WP Gazira2 resistant cultivar had the longest duration of stylet derailment (waveform F) and total probing, but lowest in total duration of pathway (waveform C), xylem ingestion (waveform G), and number of probes. Speculatively, longest duration of waveform $F$, which had a relation with the mechanical disturbance during feeding, probably is one of the possible resistant factors in Gazira2 cultivar, however this remains intriguing and needs further study.

Keywords: EPG, SEM, resistant cultivar, whole plant, detached leaves, stylet derailment

\section{Özet}

Bu çalışmada börülce yaprakbiti, Aphis craccivora Koch. (Hemiptera: Aphididae)'nin beş farklı bakla çeşidi, dayanıklı olduğu bilinen Gazira2 çeşidi dahil olmak üzere, üzerindeki beslenme davranışı EPG (Electrical Penetration Graph) yöntemi kullanılarak belirlenmiştir. Denemeler tüm bitkide (WP) ve seçilmiş yapraklarda (DL) gerçekleştirilmiştir. İstatistik analizler için 15 EPG parametresi kullanılmıştır. İstatistik sonuçları (Two-Way Factorial ANNOVA) EPG verilerinin tüm bitkide ve seçilmiş yapraklarda önemli derece farklı olduklarını göstermiştir. Börülce yaprakbitinin Gazira2 çeşidinde tüm bitki üzerinde beslenme sonuçlarına bakıldığında en uzun penetrasyon süresinin bu çeşit üzerinde olduğu, buna karşılık "waveform C" "waveform G" verilerinin ve beslenme denemesi sayıları gibi değerlerinin en kısa sureye sahip olduğu tespit edilmiştir. Dayanıklı çeşit üzerinde tespit edilen en uzun beslenme süresinin Gazira2 çeşidinin morfolojik özelliklerinden kaynaklandığı düşünülmekte olup bu konuda daha fazla çalışmaya intiyaç duyulmaktadır.

Anahtar sözcükler: EPG, SEM, dayanıklı çeşit, tüm bitki, seçilmiş yapraklar, stilet kaybolması

\footnotetext{
${ }^{1}$ Economic Entomology Research Unit (EERU), Plant Protection Department, College of Food and Agriculture Sciences, King Saud University, Riyadh, Kingdom of Saudi Arabia

* Sorumlu yazar (Corresponding author) e-mail: alsoffan@ksu.edu.sa

Alınış (Received): 18.02.2015 Kabul ediliş (Accepted): 06.01.2016

Çevrimiçi Yayın Tarihi (Published Online): 18.01.2015
} 


\section{Introduction}

Cowpea aphid, Aphis craccivora Koch. (Hemiptera: Aphididae), is a major world insect pest in agriculture (Smith \& Boyko, 2007), and in Saudi Arabia it was reported in 1989, mostly on Fabaceae (Aldryhim \& Khalil, 1993; 1996). Cowpea aphid is the key pest of faba bean, Vicia faba L. (Fabaceae), the main legume crop in Mediterranean countries and the Middle East (Nuessly et al., 2004; Saxena, 1991). Generally, aphids cause economic damage by phloem sap ingestion. The phloem sap is rich in sugars but relatively poor in amino acids, therefore, aphids need to feed on large quantities of phloem sap to meet amino acids needs (Dixon, 1998). Their role as a virus vector; such as for faba bean necrotic yellow virus (FBNYV), broad bean yellow mosaic virus (BYMV), and bean leaf roll virus (BLRV); increases the potential of this species to reduce faba bean yields (Schwinghamer et al., 2009; Hodge \& Powell, 2010; Weigand \& Bishara, 1991).

Using resistant cultivars in controlling cowpea aphid population is one of the priority tactics in integrated pest management (IPM) programs. The use of resistant cultivars is an efficient, environmentally friendly, and long term effective tactic that is synergistic with other IPM tactics (Klingler et al., 2001; Smith, 2005; Shannag \& Ja'far, 2007). However, time consuming bioassays are significant obstructions in plant breeding programs that are intended to provide resistant cultivars (Smith, 2005; Michel et al., 2011). Therefore, utilizing an efficient technique to evaluate plant cultivars resistance against insects, such as Electrical Penetration Graph (EPG) technique, is crucial (Schoonhoven et al., 1998).

Electrical Penetration Graph is one of the common tools by which it is possible to characterize and identify, in detail, plant resistance factors against insects with piercing mouthparts by monitoring their probing behaviors (Backus et al., 1994; Calatayud et al., 1994; Van Helden et al., 2000; Smith, 2005; Le Roux et al., 2008). The EPG technique was developed for the first time in the 1960s and a significant modification was made in 1978 by substitution of AC (Alternating Current) circuitry with DC (Direct Current) circuitry. The DC circuitry of EPG then simply was referred to EPG (Walker, 2000). The basic principle of EPG recording is the integration of a plant and an insect in an electronic circuit. When an aphid insert its stylet, the circuit is completed and EPG waveforms will be recorded and visualized. The waveform, i.e. voltage fluctuations, are due to electrical resistance and electromotive force changes during different activities and locations of the aphid stylet tips (Tjallingii, 1978; Montllor \& Tjallingii, 1989; Walker, 2000).

This study was conducted to evaluate cowpea aphid feeding behavior on five selected faba bean cultivars by using EPG. In particular, EPG recording was expected to reveal a possible resistance factors in cultivar Gazira2 which had been previously reported to have more resistance to cowpea aphid compared to other cultivars (Misr, Giza3i, Goff, and Misr1) (Soffan \& Aldawood, 2014).

\section{Materials and Methods}

\section{Plant material}

Five faba bean cultivars (Misr1, Misr, Giza3i, Goff1, and Gazira2) provided by Legume Research Unit (LRU), King Saud University (KSU), were used for the experiments. A mixture of sand and peat moss $(1: 1)$ were used as growth medium to germinate seeds after being soaked in water for $48 \mathrm{~h}$. One week old seedlings were transplanted to plastic pots $(\mathrm{d}: 11 \mathrm{~cm}, \mathrm{~h}: 14 \mathrm{~cm})$. When seedlings were 19 days old, one time fertilization was applied with four granules per pot of complete fertilizer $(\mathrm{N}: 12 \%, \mathrm{P}: 12 \%, \mathrm{~K}: 17 \%$; BASF-Asoco Agro, Limburgerhof). Plants were watered $150 \mathrm{ml}$ once every two days. All plants were grown in a growth chamber maintained at $26^{\circ} \mathrm{C}, 44 \%$ Relative Humidity $(\mathrm{RH})$ with a photoperiod of $16: 8$ L:D (Recorded by HOBO data loggers, ONSET Co., Bourne, MA).

Leaf surface study was conducted by Scanning Electron Microscope (SEM) (FEl company, USA) in five faba bean cultivars to investigate the presence of possible resistant factors such as trichome, wax, etc. A fresh leaf of each faba bean cultivar was observed for SEM in their native-hydrated state with $1045 \times$ magnification at $7.36 \mathrm{kv}$ and a pressure of $33 \mathrm{~Pa}$ (Pathan et al., 2008). 


\section{Cowpea aphids}

Cowpea aphids were collected from alfalfa plants grown in Al Amaria, Riyadh, Kingdom of Saudi Arabia (N: $46^{\circ} 31^{\prime} 5.5518^{\prime \prime}$ E: $\left.24^{\circ} 48^{\prime} 40.179 "\right)$. Further, a single apterous adult, virginoparous female aphid was used to initiate cowpea aphid culture on the faba bean cv Misr and was run for 8 months before the experiment. Aphid feeding behavior study was conducted in the Insect Behavior Laboratory, Economic Entomology Research Unit (EERU), Plant Protection Department, College of Food and Agriculture Sciences, King Saud University, Riyadh, Kingdom of Saudi Arabia. The environment during the feeding behavior study was maintained at $28.5^{\circ} \mathrm{C}$ and $23.5 \% \mathrm{RH}$. Cowpea aphids used in the EPG experiments were adult apterous females of 2-5 days old from a synchronized colony reared on detached leaves of faba bean cv. Misr.

\section{Aphid feeding behavior}

Cowpea aphid feeding behavior on five faba bean cultivars was monitored using a 4 channel EPG monitor (type Giga4, EPG systems, Netherlands). Whole plants (WP) at three leaf stage and detached leaves (DL) derived from the same plants were compared. Plants were placed in a Faraday cage during monitoring to exclude electrical noise. For WP EPG recording, aphids were placed on the abaxial side of the second leaf from the apex by fixing them twisted up for easy aphid access (Prado \& Tjallingii, 2007). While for the $\mathrm{DL}$, the petioles were wrapped with cotton and dipped in water in clear plastic elliptical container $(215 \mathrm{~mL}$ ) (Montllor et al., 1990) and twisted up as in WP. Aphids were attached to a thin gold wire $(20 \mu \mathrm{m}$ in diameter and $3 \mathrm{~cm}$ length) using conductive silver glue on water basis. The other end of the gold wire was attached to a three centimeters long copper wire (diameter $0.2 \mathrm{~mm}$ ) and connected to the input of the EPG amplifier, having a 1 Gigaohm input resistance and 50× gain. Each plant electrode (a $2 \mathrm{~mm}$ thick, $10 \mathrm{~cm}$ long copper rod) was connected to an adjustable EPG plant voltage output device on one side and inserted in the soil of the potted plant(WP) or the water (DL) on the other side (Prado \& Tjallingii, 2007). Four aphids at a time, one aphid per plant, were used for each $5 \mathrm{~h}$ EPG recording run (Pompon et al., 2010).

Electrical Penetration Graph waveforms were recorded on a computer, mediated by Stylet ${ }^{+}$ software, which was also used for later signal analysis (EPG Systems, Netherlands) and using AD conversion at $100 \mathrm{~Hz}$ (Di158U converter, Dataq, USA). In signal analysis, 5 EPG waveforms (C, E1, E2, $\mathrm{G}$, and $\mathrm{F}$ ) were distinguished. Waveform $\mathrm{C}$, representing the activities during stylet pathway in epidermis and mesophyll. Waveform E, total phloem phase, separated into E1 and E2 indicating sieve element salivation and phloem sap ingestion, respectively. Waveform $F$, representing stylet derailment (stylet penetration difficulties) and waveform $\mathrm{G}$, indicating xylem ingestion or active drinking of water from xylem elements (Tjallingii, 1990). Next to waveform analysis, data were processed to calculate 15 EPG parameters (Le Roux et al., 2008) using an Excel macro 'BAZ_V7. BETA' (E.S chliephacke, JKI, Quedlinburg, Germany).

\section{Experimental design and statistical analysis}

The experimental design was a complete randomized design (CRD). For each faba bean cultivar, ten replicates were used in both WP and DL.

Data were analyzed using SAS program ver. 9.2 (2008) and IBM SPSS Statistic 22. Normality test was calculated on the studentized residual of the square root transformed data. Non parametric One-way ANOVA Kruskal-Wallis was performed by using PROC NPAR1WAY, because most of the dependent variable residual data did not meet normal distribution. Two-way factorial ANOVA ( $5 \times 2 ; 5$ cultivars and 2 tissue types) were tested for those parameters which their residuals met the normality assumption. The principal component analysis (PROC PRINCOMP) was used to analyze selected six feeding behavior parameters, which were waveform C, G, F, E, non-probing duration and time from start to phloem phase. 
Electrical Penetration Graph monitored feeding behavior of cowpea aphid, Aphis craccivora Koch. (Hemiptera:Aphididae), on faba bean, Vicia faba L. (Fabaceae), cultivars

\section{Results}

Two-way factorial analysis ANOVA (5x2) was used on some parameters that met the residual normality assumption (parameters number [no.] 1, 3, 4, 11, 14, and 15; Table 1-4). It was shown that there were no interactions between tissue type (whole plant [WP] vs. detached leaf [DL]) and cultivars (Gazira2, Giza3i, Goff1, Misr1, and Misr) for all tested parameters (parameters no. 1 has $F=1.14, P=0.35$, $D F=4$; no. 3 has $F=0.93, P=0.45, D F=4$; no. 4 has $F=1.43, P=0.23, D F=4$; no. 11 has $F=0.56, P=0.69$, $D F=4$; no. 14 has $F=0.47, P=0.76, D F=4$; and no. 15 has $F=0.19, P=0.94, D F=4$ ). As main effect, tissue type (WP and DL) showed significant difference for all parameters above $(F=14.7-59.8, P<0.05, D F=1)$. The data values between WP and DL were obviously different on some parameters such as total duration of pathway phase (waveform C, parameter no. 4), total duration of phloem ingestion periods (waveform E2, parameter no. 12), and time from start to first sustained phloem ingestion (parameter no. 15).

Table 1. Non-Phloem feeding behavior of cowpea aphid during 5 -h access on five faba bean cultivars (Means \pm SE) $)^{1,2,3}$

\begin{tabular}{|c|c|c|c|c|c|c|}
\hline \multirow{2}{*}{\multicolumn{2}{|c|}{$\begin{array}{l}\text { Non Phloem feeding } \\
\text { Parameters }\end{array}$}} & \multicolumn{5}{|c|}{ Cultivars } \\
\hline & & Gazira2 & Misr & Giza3i & Goff1 & Misr1 \\
\hline \multicolumn{7}{|c|}{ General probing behavior } \\
\hline \multirow{3}{*}{$\begin{array}{l}\text { 1. Number of } \\
\text { probes }(n)\end{array}$} & WP & $13.8 \pm 3.6 b$ & $30.1 \pm 2.7 a$ & $17.9 \pm 3.5 b$ & $19.1 \pm 4.4 b$ & $16.6 \pm 3.1 b$ \\
\hline & $\mathrm{DL}$ & $5.2 \pm 1.4 a$ & $9 \pm 2.4 a$ & $5.6 \pm 1.6 a$ & $7.4 \pm 2.5 a$ & $10 \pm 2.8 a$ \\
\hline & $P$ & $0.026^{*}$ & $0.001^{*}$ & $0.01^{*}$ & $0.04^{*}$ & $0.112^{\mathrm{ns}}$ \\
\hline \multirow{3}{*}{$\begin{array}{l}\text { 2. Total duration } \\
\text { of probing (min) }\end{array}$} & WP & $279.5 \pm 6.1 \mathrm{a}$ & $257.6 \pm 6.9 b$ & $242.1 \pm 18.2 b$ & $264.4 \pm 10.8 a b$ & $276.1 \pm 5.8 a b$ \\
\hline & $\mathrm{DL}$ & $293.1 \pm 3.5 a$ & $288 \pm 5 a$ & $292.9 \pm 3.4 a$ & $292.6 \pm 3.4 a$ & $289.1 \pm 3.6 a$ \\
\hline & $P$ & $0.036^{*}$ & $0.004^{*}$ & $0.002^{*}$ & $0.015^{*}$ & $0.153^{n s}$ \\
\hline \multicolumn{7}{|l|}{ Pathway phase } \\
\hline \multirow{3}{*}{$\begin{array}{l}\text { 3. Number of } \\
\text { pathway phase } \\
\text { (waveform C) (n) }\end{array}$} & WP & $18.6 \pm 3.1 b$ & $31.2 \pm 2.8 a$ & $19.5 \pm 3.5 b$ & $21 \pm 4.3 b$ & $19 \pm 3 b$ \\
\hline & $\mathrm{DL}$ & $8 \pm 2.1 a$ & $10 \pm 2.6 a$ & $6.3 \pm 1.7 a$ & $8.3 \pm 2.6 a$ & $11.4 \pm 3.3 a$ \\
\hline & $P$ & $0.012^{*}$ & $0.002^{*}$ & $0.009^{*}$ & $0.019^{*}$ & $0.1^{\mathrm{ns}}$ \\
\hline \multirow{3}{*}{$\begin{array}{l}\text { 4. Total duration } \\
\text { of pathway } \\
\text { phase } \\
\text { (waveform C) }\end{array}$} & WP & $143.5 \pm 21.8 b$ & $211.8 \pm 11.3 a$ & $191.9 \pm 19.6 a b$ & $161.3 \pm 21.1 \mathrm{ab}$ & $166.1 \pm 22.4 a b$ \\
\hline & $\mathrm{DL}$ & $90.4 \pm 18.9 a$ & $78.2 \pm 15.9 a$ & $75.6 \pm 19.2 a$ & $90.9 \pm 25.6 a$ & $63.4 \pm 8.2 a$ \\
\hline & $P$ & $0.142^{\mathrm{ns}}$ & $0.001^{*}$ & $0.003^{*}$ & $0.06^{\text {ns }}$ & $0.007^{*}$ \\
\hline \multirow{3}{*}{$\begin{array}{l}\text { 5. Time from } \\
\text { start to first } \\
\text { probe (min) }\end{array}$} & WP & $0.9 \pm 0.7 a$ & $0.1 \pm 0.1 a$ & $19.1 \pm 18.5 a$ & $0.02 \pm 0 a$ & $0.2 \pm 0.2 a$ \\
\hline & $\mathrm{DL}$ & $0.02 \pm 0 a$ & $0.4 \pm 0.4 a$ & $0.08 \pm 0.04 a$ & $0.02 \pm 0 a$ & $10.1 \pm 10.1 a$ \\
\hline & $P$ & $0.441^{\mathrm{ns}}$ & $0.864^{\mathrm{ns}}$ & $1^{\mathrm{ns}}$ & $1^{\mathrm{ns}}$ & $0.781^{\mathrm{ns}}$ \\
\hline
\end{tabular}

${ }^{1}$ WP:Whole plant; DL: Detached leaf; $P$ : P-value,

${ }^{2}$ Means followed by the same letter in the same row are not significantly different at LSD, $\alpha=0.05$,

${ }^{3}$ Means in the same column for each parameter comparing whole plants (WP) and detached leaves (DL) accompanied with P-value, asterisk $\left(^{*}\right)$ for significant difference, $n s$ is non-significant at $\alpha=0.05$.

Principle component analysis showed similar results related to tissue type above. The first three main components of the principle component analysis (Figure 1) explained $96 \%$ of the variability of aphid feeding among plant cultivars (62\%, 19\%, and 15\%). Significant difference between WP and DL assays were indicated from the clear separation in plotting component 1 against component 2.

Non-parametric one-way ANOVA Kruskal-Wallis test on different cultivars showed that significant difference among cultivars mostly occurred in WP tissue, while DL did not give any significant difference among cultivars for all parameters (Table 1). Among five cultivars, Gazira2 had a significant association with the lowest number of probes, lowest number and total duration of waveform $\mathrm{C}$, and highest total probing duration as compared to cultivar Misr. Cultivar Gazira2 was significantly the highest in total 
duration of stylet derailment (waveform F) periods among all cultivars. Cultivar Misr had a significant association with the highest number of probes and number of waveform $\mathrm{C}$ among all cultivars. Cultivar Misr was one of the four cultivars which has lower total duration of waveform $F$ and lowest total duration of waveform E2. Cultivar Giza3i, Goff1, and Misr1 were among the four cultivars which had low number of probes, total duration of probing, number and duration of waveform $\mathrm{C}$, and total duration of waveform $\mathrm{F}$.

Table 2. Non-Phloem feeding behavior (waveform G and F) of cowpea aphid during 5-h access on five faba bean cultivars (Means $\pm \mathrm{SE})^{1,2,3}$

\begin{tabular}{|c|c|c|c|c|c|c|}
\hline \multirow{2}{*}{$\begin{array}{l}\text { Non Phloem feeding } \\
\text { Parameters }\end{array}$} & & \multicolumn{5}{|c|}{ Cultivars } \\
\hline & & Gazira2 & Misr & Giza3i & Goff1 & Misr1 \\
\hline \multicolumn{7}{|l|}{ Other parameters } \\
\hline \multirow{3}{*}{$\begin{array}{l}\text { 6. Total duration of } \\
\text { xylem ingestion } \\
\text { (waveform G) (min) }\end{array}$} & WP & $5.9 \pm 5.9 a$ & $8 \pm 5.5 a$ & $10.1 \pm 8.3 a$ & $18.1 \pm 10.4 a$ & $35.1 \pm 17.7 a$ \\
\hline & $\mathrm{DL}$ & $20.3 \pm 15.2 a$ & $7.7 \pm 7.7 a$ & $13.1 \pm 12.2 a$ & $3.4 \pm 3.4 a$ & $6.9 \pm 6.9 a$ \\
\hline & $P$ & $0.538^{\mathrm{ns}}$ & $0.718^{\mathrm{ns}}$ & $0.792^{\text {ns }}$ & $0.359^{\mathrm{ns}}$ & $0.177^{\mathrm{ns}}$ \\
\hline \multirow{3}{*}{$\begin{array}{l}\text { 7. Total duration of } \\
\text { stylet derailment } \\
\text { (waveform F) (min) }\end{array}$} & WP & $98.9 \pm 21.3 a$ & $23.7 \pm 12.2 b$ & $15.4 \pm 7.9 b$ & $19.6 \pm 9.1 b$ & $38.5 \pm 18.7 b$ \\
\hline & $\mathrm{DL}$ & $0.5 \pm 0.2 a$ & $23.5 \pm 13.5 a$ & $23.4 \pm 11.9 a$ & $8.8 \pm 8.8 a$ & $49.1 \pm 20.8 a$ \\
\hline & $P$ & $0.006^{*}$ & $0.917^{\mathrm{ns}}$ & $0.85^{\mathrm{ns}}$ & $0.333^{\mathrm{ns}}$ & $0.735^{\mathrm{ns}}$ \\
\hline
\end{tabular}

${ }^{1}$ WP:Whole plant; DL: Detached leaf; $P$ : P-value

${ }^{2}$ Means followed by the same letter in the same row are not significantly different at LSD, $\alpha=0.05$

${ }^{3}$ Means in the same column for each parameter comparing whole plants (WP) and detached leaves (DL) accompanied with P-value, asterisk ( $\left.{ }^{*}\right)$ for significant difference, $n s$ is non-significant at, $\alpha=0.05$.

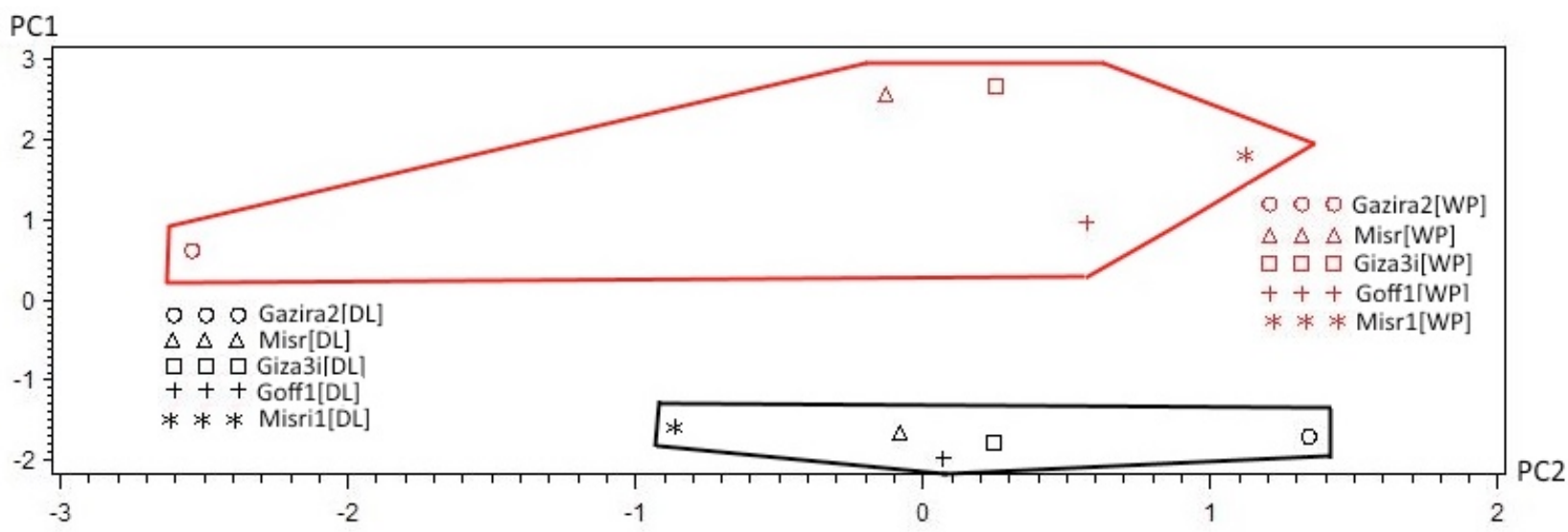

Figure 1. Principal Component Analysis plot PC1(62\%) vs. PC2 (19\%), for all cultivars (whole plants-WP-and detached leaves -DL-) using data of Non probing duration, pathway phase duration (waveform C), xylem ingestion duration (Waveform $\mathrm{G}$ ), stylet derailment duration (waveform $\mathrm{F}$ ), total phloem duration (waveform E), and time from start to phloem phase. PC:Principle component.

Scanning electron microscope for lower leaf surface revealed that there were no trichomes in all cultivars, which may suggest plant defense implications (Figure 2). 

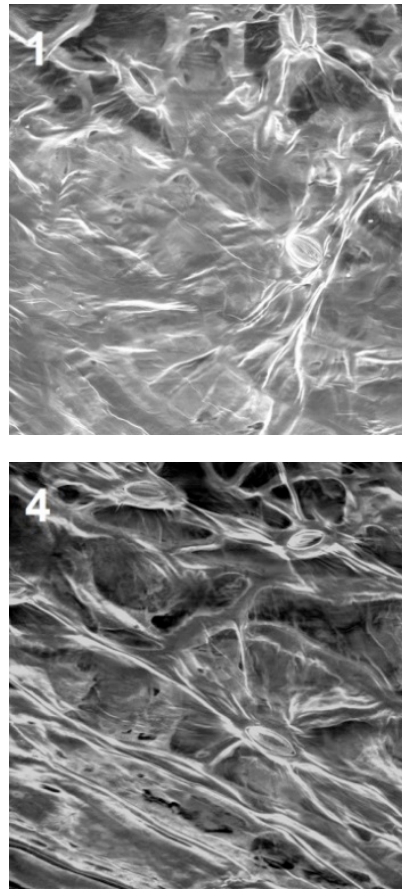
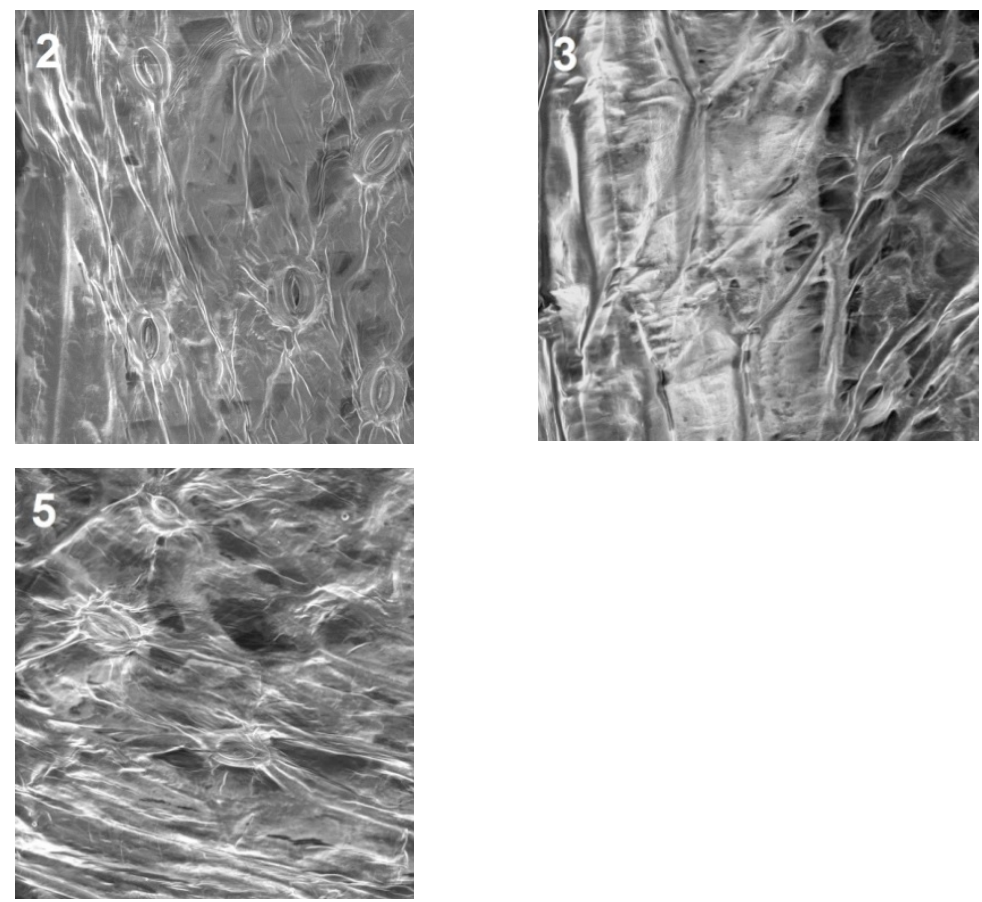

Figure 2. Scanning electron microscopic images of the lower leaf epidermis surface of five faba bean cultivars, 1). Gazira2, 2). Misr, 3). Giza3i, 4). Goff1, 5). Misr1.

Table 3. Phloem salivation feeding behavior of cowpea aphid during 5-h access on five faba bean cultivars (Means $\pm \mathrm{SE})^{1,2,3}$

\begin{tabular}{|c|c|c|c|c|c|c|}
\hline \multirow{2}{*}{$\begin{array}{l}\text { Phloem feeding } \\
\text { Parameters }\end{array}$} & & \multicolumn{5}{|c|}{ Cultivars } \\
\hline & & Gazira2 & Misr & Giza3i & Goff1 & Misr1 \\
\hline \multicolumn{7}{|c|}{ Phloem salivation phase } \\
\hline \multirow{3}{*}{$\begin{array}{l}\text { 8. Number of single } \\
\text { waveform } \mathrm{E} 1 \\
\text { salivation }(n) \text { (single } \\
\mathrm{E} 1=\text { without } \mathrm{E} 2)\end{array}$} & WP & $0.2 \pm 0.2 a$ & $0.1 \pm 0.1 a$ & Oa & $0.1 \pm 0.1 \mathrm{a}$ & $0 a$ \\
\hline & $\mathrm{DL}$ & 0 & 0 & 0 & 0 & 0 \\
\hline & $P$ & $0.317^{\mathrm{ns}}$ & $0.346^{\mathrm{ns}}$ & $1^{\mathrm{ns}}$ & $0.403^{\mathrm{ns}}$ & $1^{\mathrm{ns}}$ \\
\hline \multirow{3}{*}{$\begin{array}{l}\text { 9. Total duration } \\
\text { single waveform E1 } \\
\text { salivation ( } \min \text { ) }\end{array}$} & WP & $0.2 \pm 0.2 a$ & $0.06 \pm 0.06 a$ & $0 a$ & $0.04 \pm 0.04 a$ & $0 a$ \\
\hline & $\mathrm{DL}$ & 0 & 0 & 0 & 0 & 0 \\
\hline & $P$ & $0.317^{\mathrm{ns}}$ & $0.346^{\mathrm{ns}}$ & $1^{\text {ns }}$ & $0.403^{\mathrm{ns}}$ & $1^{\mathrm{ns}}$ \\
\hline \multirow{3}{*}{$\begin{array}{l}\text { 10. Total duration } \\
\text { waveform. E1 } \\
\text { fractions (E1 } \\
\text { followed by E2) }\end{array}$} & WP & $30.9 \pm 16.3 a b$ & $14.1 \pm 9.2 b$ & $24.6 \pm 12.8 a b$ & $65.2 \pm 19.7 a$ & $36.4 \pm 20.3 a b$ \\
\hline & $\mathrm{DL}$ & $181.6 \pm 32.7 a$ & $178.5 \pm 25.2 a$ & $180.8 \pm 29.7 a$ & $189.4 \pm 33.9 a$ & $169.6 \pm 22.3 a$ \\
\hline & $P$ & $0.006^{*}$ & $0.001^{*}$ & $0.001^{*}$ & $0.006^{*}$ & $0.004^{*}$ \\
\hline \multirow{3}{*}{$\begin{array}{l}\text { 11. Time from start } \\
\text { to first phloem } \\
\text { salivation, waveform } \\
\text { E1 (min) }\end{array}$} & WP & $149.8 \pm 46.5 a$ & $234.7 \pm 16.1 \mathrm{a}$ & $226.1 \pm 28.8 a$ & $154.9 \pm 31.4 a$ & $218.5 \pm 26.4 a$ \\
\hline & $\mathrm{DL}$ & $109.2 \pm 29.8 a$ & $121.6 \pm 25.2 a$ & $118.8 \pm 31.9 a$ & $109.8 \pm 34.2 a$ & $133.5 \pm 25.9 a$ \\
\hline & $P$ & $0.221^{\mathrm{ns}}$ & $0.017^{*}$ & $0.028^{*}$ & $0.203^{\mathrm{ns}}$ & $0.055^{\mathrm{ns}}$ \\
\hline
\end{tabular}

${ }^{1}$ WP:Whole plant; DL: Detached leaf; $P$ : P-value

${ }^{2}$ Means followed by the same letter in the same row are not significantly different at LSD, $\alpha=0.05$

${ }^{3}$ Means in the same column for each parameter comparing whole plants (WP) and detached leaves (DL) accompanied with P-value, asterisk (*) for significant difference, $n s$ is non-significant at, $\alpha=0.05$. 
Table 4. Phloem Ingestion feeding behavior of cowpea aphid during 5-h access on five faba bean cultivars (Means \pm $\mathrm{SE})^{1,2,3}$

\begin{tabular}{|c|c|c|c|c|c|c|}
\hline \multirow{2}{*}{$\begin{array}{l}\text { Phloem feeding } \\
\text { Parameters }\end{array}$} & & \multicolumn{5}{|c|}{ Cultivars } \\
\hline & & Gazira2 & Misr & Giza3i & Goff1 & Misr1 \\
\hline \multicolumn{7}{|l|}{ Phloem ingestion phase } \\
\hline \multirow{3}{*}{$\begin{array}{l}\text { 12. Total duration of } \\
\text { phloem ingestion } \\
\text { (waveform E2) periods } \\
\text { (min) }\end{array}$} & WP & $28.1 \pm 15.5 a b$ & $10.9 \pm 8.6 b$ & $20.4 \pm 11.1 \mathrm{ab}$ & $54.7 \pm 16.5 a$ & $30.6 \pm 19.3 a b$ \\
\hline & $\mathrm{DL}$ & $176.1 \pm 33.4 a$ & $176.2 \pm 25.1 a$ & $175.8 \pm 30.8 a$ & $184.8 \pm 34.2 a$ & $167.2 \pm 22.8 a$ \\
\hline & $P$ & $0.006^{*}$ & $0.001^{*}$ & $0.001^{*}$ & $0.006^{*}$ & $0.004^{*}$ \\
\hline \multirow{3}{*}{$\begin{array}{l}\text { 13. Total duration of } \\
\text { sustained phloem } \\
\text { ingestion } \\
\text { (Waveform E2) (min) }\end{array}$} & WP & $27.3 \pm 15.1 \mathrm{ab}$ & $10.8 \pm 8.6 b$ & $18.3 \pm 10.6 a b$ & $53.1 \pm 16.4 a$ & $28.8 \pm 19.4 a b$ \\
\hline & $\mathrm{DL}$ & $175.7 \pm 33.4 a$ & $176.1 \pm 25.1 a$ & $174.7 \pm 31.2 \mathrm{a}$ & $183.4 \pm 34.1 \mathrm{a}$ & $165.7 \pm 23.4 a$ \\
\hline & $P$ & $0.004^{*}$ & $0.001^{*}$ & $0.0004^{*}$ & $0.006^{*}$ & $0.003^{*}$ \\
\hline \multirow{3}{*}{$\begin{array}{l}\text { 14. Time from start to } \\
\text { first phloem ingestion } \\
\text { (waveform E2) (min) }\end{array}$} & WP & $148.2 \pm 47.9 a$ & $246.2 \pm 15.6 a$ & $192.6 \pm 33.1 \mathrm{a}$ & $154.4 \pm 31.58 a$ & $218.2 \pm 26.4 a$ \\
\hline & $\mathrm{DL}$ & $89.6 \pm 24.1 a$ & $121.1 \pm 25.3 a$ & $110.9 \pm 29.2 a$ & $109.6 \pm 34.2 a$ & $120.1 \pm 23.1 \mathrm{a}$ \\
\hline & $P$ & $0.186^{\mathrm{ns}}$ & $0.025^{*}$ & $0.077^{\mathrm{ns}}$ & $0.203^{\mathrm{ns}}$ & $0.022^{*}$ \\
\hline \multirow{3}{*}{$\begin{array}{l}\text { 15. Time from start to } \\
\text { first sustained phloem } \\
\text { ingestion } \\
\text { (waveform E2 > } 10 \mathrm{~min} \text { ) }\end{array}$} & WP & $225.5 \pm 23.1 a$ & $251.2 \pm 28.5 a$ & $202.9 \pm 17.6 a$ & $205.7 \pm 29.4 a$ & $202.3 \pm 45 a$ \\
\hline & $\mathrm{DL}$ & $96.7 \pm 24.5 a$ & $123.6 \pm 25.1 a$ & $111.5 \pm 29.2 a$ & $114.2 \pm 34.5 a$ & $124.1 \pm 24.6 a$ \\
\hline & $P$ & $0.017^{*}$ & $0.068^{\mathrm{ns}}$ & $0.079^{\mathrm{ns}}$ & $0.064^{\mathrm{ns}}$ & $0.139^{\mathrm{ns}}$ \\
\hline
\end{tabular}

${ }^{1} \mathrm{WP}:$ Whole plant; DL: Detached leaf; $P$ : P-value

${ }^{2}$ Means followed by the same letter in the same row are not significantly different at LSD, $\alpha=0.05$

${ }^{3}$ Means in the same column for each parameter comparing whole plants (WP) and detached leaves (DL) accompanied with P-value, asterisk $\left(^{*}\right)$ for significant difference, $n s$ is non-significant at, $\alpha=0.05$.

\section{Discussion}

Understanding the resistance factors of faba bean cultivars against cowpea aphid is crucial in plant breeding program. Field screening (Ebadah et al., 2006, Shannag \& Ja'far, 2007) or biological assays are lacking detailed information on how plants defend themselves against aphids (Abdel-Hafiz, 2008; Sharma et al., 2005; Narayanamma et al., 2007; Michel et al., 2010). Both techniques are not sufficient to identify the resistance factors. Therefore, Electrical Penetration Graph (EPG) can be used as an alternative method to get detailed information on this issue (Van Helden et al., 2000; Le Roux et al., 2008).

Whole plant (WP) or detached leaf (DL) bioassays, both had been used extensively in many aphidplant interaction studies (Michel et al., 2010; Montllor et al., 1990; Nam \& Hardie, 2012; Soffan \& Aldawood, 2014). Depending on bioassay type, both might generate similar or different results for the same host cultivar (Montllor et al., 1990; Nam \& Hardie, 2012). In this study, most of EPG parameters values between WP and DL were significantly different as indicated by two way factorial analysis and principle component analysis. The data of WP and DL were obviously different for some parameters such as in total duration of waveform F (parameter no.7). Gazira2 had a significantly highest value in WP (98.9 $\min$ ), while in DL the value dropped to $0.5 \mathrm{~min}$. Moreover, parameters values in DL are significantly higher than WP, as in total duration of waveform E1 and E2 (parameter no. 12 and 13), or significantly lower, such as in time from start to first phloem ingestion (parameters no. 14 and 15). This typical phenomena was noted in Greenbugs, Schizaphis graminum (Rondani) (Hemiptera: Aphididae), that performed different feeding behaviors on several EPG parameters between WP and DL, especially on resistant cultivar of sorghum (Montllor et al., 1990; Van Emden \& Bashford, 1976).

Generally, DLs represent a better food sources and are more acceptable compared to WPs (Tune \& Dussourd, 2000, Huang et al., 2003), for instance, Greenbugs, Schizaphis graminum (Rondani) (Homoptera: Aphididae) grew better on DL as compared to WP on the same sorghum, Sorghum bicolor 
(Poaceae), varieties (Montllor et al., 1990). Leaf excision on DL also had been suggested to trigger the change of integrity or composition of middle lamellar polysaccharides (Montllor et al., 1990; Van Emden \& Bashford, 1976). If we assumed that DL were more exposed to water than WP in order to keep DL fresh during the study (by wrapping the leaf petiole with wet cotton), then it can be speculated that the difference in cowpea aphid feeding behavior between WP and DL might be due to the alteration of metabolite concentrations, such as sucrose and several amino acids (Mewis et al., 2012) or it might be associated with the thickening of the cell in the WP (Cutler et al., 1977).

In this EPG study, cultivars differences in DL were masked statistically. Similar result was obtained on Brevicoryne brassicae L. ( Hemiptera: Aphididae) biological performance when resistant and susceptible brussels sprout plant (Brassica oleracea: Brassicaceae) were compared (Van Emden \& Bashford, 1976), also the failure of Diabrotica balteata LeConte (Coleoptera: Chrysomelidae) to show resistant characteristics of lettuce (Lactuca sativa L.: Asteraceae) cv Valmaine in DL (Huang et al., 2003). Therefore, cultivars analysis for EPG study in WP was preferred, although the use of DL can be fit in other type of bioassays, as they have different aphid-host interaction (Michel et al., 2010; Soffan \& Aldawood, 2014).

While in WP tissue, some of the feeding behavior parameters showed different values among five cultivars. One of the important resistance indicators, which is initial recognition of the plant tissue before the start of ingestion (Gabrys \& Tjallingii, 2002), failed to describe the difference among cultivars. Time from start to first probe (Parameter no. 5) showed a negligible value for all cultivars, indicating there was no resistance factor on the surface of the leaf. This fact was confirmed by leaf surface observation through scanning electron microscope (Figure 2), which showed that there was no trichome or wax layer structures that might disturb aphid stylet penetration (Powell et al., 1999, Perdikis et al., 2008, Vallejo et al., 1994). A large number of test probes and a long time until the first phloem phase activity, commonly indicate the resistance factor in peripheral layers of plant tissue (i.e., epidermis and mesophyll) (Alvarez et al., 2006). However, they were not present in the studied resistant cultivar Gazira2. Phloem feeding phase (Table 3.), which is one of the important indicators of aphid resistance (Annan et al., 1997, Tjallingii, 1990), also had no clear cut significance, cowpea aphid had an ability to reach the phloem sieve tissue in all of the cultivars, as well as to have normal phloem ingestion duration, as these values were similar to other reported study (Prado \& Tjallingii, 2007).

The associative feeding behavior of resistant cultivar Gazira2 only includes longest duration of stylet derailment (waveform F) and probing, but lowest in total duration of pathway (waveform C), xylem ingestion (waveform G), and number of probes. Among these parameters profile in Gazira2, a significantly highest waveform $\mathrm{F}$ duration might be the possible resistance factor, as it occurred only in Gazira2. This result had been speculated to have an association with aphid feeding behavioral disturbance in plant cells (stylet penetration difficulties) (Tjallingii, 1990), especially when compared to the nearly vanish of this waveform in $\mathrm{DL}$ from 98.9 to 0.5 min (Table 2, parameter no 7). A similar, but less pronounced conclusion, was made for the aphid Nasonovia ribisnigri (Mosley) (Hemiptera: Aphididae), which performed longer waveform $F$ on resistant lettuce line (Montllor \& Tjallingii, 1989). Since the DL came from the same plants as in WP, it indicated that the DL tissue of Gazira2 had lost their resistance factor, as it occurred in other study (Montllor et al., 1990). One might guess why this did not happen in the other cultivars, and this aspect certainly needs further research.

Finally this study presented evidence that cowpea aphid feeding behavior on WP and DL of faba bean was different as recorded by EPG. The EPG data showed that WP tissue were more appropriate to be used in evaluating faba bean cultivars resistance to cowpea aphid. A reported resistant cultivar Gazira2 had no association neither with phloem factor nor leaf surface factor, rather, it possibly had relation with the longer duration of stylet derailment (waveform F), which was not retained on the DL. Nevertheless, this result remains intriguing and may possibly provide a cue for further research. 


\section{Acknowledgements}

We thank to Dr. Tjallingii for the EPG technique and review of this paper, Prof. Yousif $\mathrm{N}$. Aldryhim for guidance in working with aphid, and all colleagues in EERU for their support. This study was supported by student research grant (A-S-11-0813) King Abdulaziz City for Science and Technology (KACST).

\section{References}

Abdel-Hafiz, N.A, 2008. Resistance of certain cucumber varieties to the melon aphid Aphis gossypii (Glover). Zemdirbyste-Agriculture, 95: 293-297.

Aldryhim, Y. \& A. Khalil, 1993. Influence of temperature and daylength on population development of Aphis gossypii on Cucurbita pepo. Entomologia Experimentalis et Applicata, 67:167-172.

Aldryhim, Y. \& A. Khalil, 1996. The Aphididae of Saudi Arabia. Fauna of Saudi Arabia, 15:161-195.

Alvarez, A., W.F. Tjallingii, E. Garzo, V. Vleeshouwers, M. Dicke \& B. Vosman, 2006. Location of resistance factors in the leavess of potato and wild tuber-bearing Solanum species to the aphid Myzus persicae. Entomologia Experimentalis et Applicata, 121:145-157.

Annan, I.B., G.A Schaefers, W. Tingey \& W.F Tjallingii, 1997. Effects of treatments for electrical penetration graph recordings on behavior and biology of Aphis craccivora (Aphididae). Physiological Entomology, 22:95-101.

Backus, E. A. 1994. "History, development, and applications of the AC electronic monitoring system for insect feeding, pp. 1-51." In M. M. Ellsbury, E. A. Backus, and D. L. Ullman (eds.), History, Development, and Application of AC Electronic Insect Feeding Monitors. Entomological Society of America, Lanham, MD, $128 \mathrm{pp}$.

Calatayud, P.A., Y. Rahbé, W.F Tjallingii, M. Tertuliano \& B. Le Rü, 1994. Electrically recorded feeding behaviour of cassava mealybug on host and non-host plants. Entomologia Experimentalis et Applicata, 72:219-232.

Cutler, J.M., D.W Rains, \& R. Loomis, 1977. The importance of cell size in the water relations of plants. Physiologia Plantarum, 40:255-260.

Dixon, A.F.G., 1998. Aphid ecology: an optimization approach. Chapman and Hall, London, UK, 300 pp.

Ebadah, I., Y. Mahmoud \& S.Moawad, 2006. Susceptibility of some faba bean cultivars to field infestation with some insect pests. Research Journal of Agriculture and Biological Sciences, 2:537-540.

Gabrys, B., \& W.F. Tjallingii, 2002. The role of sinigrin in host plant recognition by aphids during initial plant penetration. Entomologia Experimentalis et Applicata, 104:89-93.

Hodge, S.,\& G. Powell, 2010. Conditional facilitation of an aphid vector, Acyrthosiphon pisum, by the plant pathogen, Pea Enation Mosaic Virus. Journal of Insect Science, DOI: 10.1673/031.010.14115. insectscience.org/10.155.

Huang, J., G.S. Nuessly, H.J McAuslane \& R.T Nagata, 2003. Effect of screening methods on expression of romaine lettuce resistance to adult banded cucumber beetle, Diabrotica balteata (Coleoptera: Chrysomelidae). Florida Entomologist, 86: 194-198.

Klingler, J., I. Kovalski, L. Silberstein, G. Thompson \& R. Perl-Treves, 2001. Mapping of cotton-melon aphid resistance in melon. Journal of the American Society for Horticultural Science, 126:56-63.

Le Roux, V., S. Dugravot, E. Campan, F. Dubois, C. Vincent \& P. Giordanengo, 2008. Wild solanum resistance to aphids: antixenosis or antibiosis? Journal of Economic Entomology, 101: 584-591.

Mewis, I., M.A.M Khan, E. Glawischnig, M. Schreiner \& C. Ulrichs, 2012. Water stress and aphid feeding differentially influence metabolite composition in Arabidopsis thaliana (L.). PloS One, 7:1-15. 
Michel, A.P., M.A Mian, N.H Davila-Olivas \& L.A Cañas, 2010. Detached leaf and whole plant assays for soybean aphid resistance: differential responses among resistance sources and biotypes. Journal of Economic Entomology, 103: 949-957.

Michel, A.P., O. Mittapalli \& M.A.R. Mian, 2011. Evolution of Soybean Aphid Biotypes: Understanding and Managing Virulence to Host-Plant Resistance, 356-372. In: Soybean - Molecular Aspects of Breeding, (Ed: A. Sudaric), InTech, 526 p. ISBN: 978-953-307-240-1, DOI: 10.5772/14407. Available from: http://www.intechopen.com/books/soybean-molecular-aspects-ofbreeding/evolution-of-soybean-aphid-biotypes-understanding-and-managing-virulence-to-hostplant-resistance.

Montllor, C. \& W. F. Tjallingii, 1989. Stylet penetration by two aphid species on susceptible and resistant lettuce. Entomologia Experimentalis et Applicata, 52:103-111.

Montllor, C.B., B.C Campbell \& T. E., Mittler, 1990. Responses of Schizaphisgraminum (Homoptera: Aphididae) to leaf excision in resistant and susceptible sorghum. Annals of Applied Biology, 116: 189-198.

Nam, K.J. \& J. Hardie, 2012. Reproduction and probing behaviour of the bird cherry-oat aphid Rhopalosiphumpadi on detached leaves and leaves on intact seedlings of the winter host, bird cherry Prunuspadus. Physiological Entomology, 37:196-200.

Narayanamma, V.L., H. Sharma, C.L.L Gowda \& M.Sriramulu, 2007. Mechanisms of resistance to Helicoverpa armigera and introgression of resistance genes into F1 hybrids in chickpea. Arthropod-Plant Interactions, 1:263-270.

Nuessly, G.S., M.G. Hentz, R. Beiriger \& B.T. Scully, 2004. Insects associated with faba bean, Viciafaba (Fabales: Fabaceae), in southern Florida. Florida Entomologist, 87: 204-211.

Pathan, A., J. Bond \& R. Gaskin, 2008. Sample preparation for scanning electron microscopy of plant surfaces-Horses for courses. Micron 39:1049-1061.

Perdikis, D., E. Kapaxidi \& G. Papadoulis, 2008. Biological control of insect and mite pests in greenhouse Solanaceous crops. The European Journal of Plant Science and Biotechnology, 2:125-144.

Pompon, J., D. Quiring, P. Giordanengo \& Y. Pelletier, 2010. Role of xylem consumption on osmoregulation in Macrosiphum euphorbiae (Thomas). Journal of Insect Physiology, 56:610-615.

Powell, G., S.P. Maniar, J.A. Pickett \& J.Hardie, 1999. Aphid responses to non-host epicuticular lipids. Entomologia Experimentalis et Applicata, 91:115-123.

Prado, E. \& W.F. Tjallingii, 1997. Effects of previous plant infestation on sieve element acceptance by two aphids. Entomologia Experimentalis et Applicata, 82:189-200.

Prado, E. \& W.F. Tjallingii, 2007. Behavioral evidence for local reduction of aphid-induced resistance. Journal of Insect Science, 7:1-8.

SAS Institute Inc., 2008. SAS/STAT 9.2 User's Guide, SAS Institute Inc., Cary, NC

Saxena, M., 1991. Status and scope for production of faba bean in the Mediterranean countries." Options Méditerranéennes, 15-20.

Schoonhoven, L.M., T. Jermy \& J.J.A. van Loon, 1998. Insect-plant biology: From physiology to evolution. Chapman and Hall, London and New York, 409 pp.

Schwinghamer, M., A. Nicholas \& M.Schilg, 2009. Three aphid vectors of faba bean (Viciafaba) viruses in northern New South Wales and occurrence of Acyrthosiphonpisum-transmitted isolates of Soybean dwarf virus. Australasian Plant Pathology, 38:262-269.

Shannag, H. \& A. Ja'far, 2007. Biometry and responses of faba bean varieties to black bean aphid, Aphis fabae Scopoli. American-Eurasian Journal of Agriculture \& Environmental Science, 2:328-334. 
Sharma, H.C., G. Pampapathy, M.K. Dhillon \& J.T. Ridsdill-Smith, 2005. Detached leaf assay to screen for host plant resistance to Helicoverpa armigera. Journal of Economic Entomology, 98:568-576.

Smith, C.M., 2005. Plant resistance to arthropods: molecular and conventional approaches. Springer, Netherland, $423 \mathrm{pp}$.

Smith, C.M. \& E.V. Boyko, 2007. The molecular bases of plant resistance and defense responses to aphid feeding: current status. Entomologia Experimentalis et Applicata, 122:1-16.

Soffan, A. \& A.S. Aldawood, 2014. Biology and demographic growth parameters of cowpea aphid (Aphis craccivora) on faba bean (Vicia faba) cultivars. Journal of Insect Science, 14:1-10.

Tjallingii, W.F., 1978. Electronic recording of penetration behaviour by aphids. Entomologia Experimentalis et Applicata, 24:721-730.

Tjallingii, W.F., 1990. Continuous recording of stylet penetration activities by aphids. Aphid-plant genotype interactions. Elsevier, Amsterdam, 89-99 pp.

Tune, R. \& D.E. Dussourd, 2000. Specialized generalists: constraints on host range in some plusiine caterpillars. Oecologia, 123:543-549.

Vallejo, R.L., W.W. Collins \& R.H. Moll, 1994. Inheritance of A and B glandular trichome density and polyphenol oxidase activity in diploid potatoes. Journal of the American Society for Horticultural Science, 119:829-832.

Van Emden, H.F. \& M.A. Bashford, 1976. The effect of leaf excision on the performance of Myzuspersicae and Brevicoryne brassicae in relation to the nutrient treatment of the plants. Physiological Entomology, 1: 67-71.

Van Helden, M., W.F. Tjallingii, G.P. Walker \& E.A. Backus, 2000. Experimental design and analysis. In EPG experiments with emphasis on plant resistance research. Principles and applications of electronic monitoring and other techniques in the study of homopteran feeding behavior. Thomas Say Publications in Entomology, Entomological Society of America, Lanham, MD, 144-171 pp.

Walker, G.P., 2000. A Beginner's guide to electronic monitoring of homopteran probing behavior. In: Walker GP and Backus EA editor. Principles and applications of electronic monitoring and other techniques in the study of homopteran feeding behavior. Proceedings of the symposium at the XIX international congress of entomology, Entomological Society of America,Beijing, China., 14$40 \mathrm{pp}$.

Weigand, S.,\& S.I. Bishara, 1991. Status of insect pests of faba bean in the Mediteranean region and methods of control. In: Cubero $\mathrm{JI}$ and Saxena MC editor. Present status and future prospects of faba bean production and improvement in the Mediterranean countries. Zaragoza: CIHEAM, 6774 pp (Options Méditerranéennes:Série A. Séminaires Méditerranéens; n.10). 